\title{
In Celebration of Willi Steiner
}

\author{
Jules Winterton, Librarian and Deputy Director, Institute of Advanced Legal \\ Studies
}

In May 2003, I had the sad duty to distribute a notice of Willi Steiner's death to colleagues; the brief notice is reproduced below. On 27 May an obituary appeared in the Times written by Willi's brother Francis. This article is an opportunity to mark Willi's passing with a substantial account of his career and contribution to the profession of law librarianship and to the process of research and scholarship in law. I would like to thank David Wills, Squire Law Librarian, and Paul Norman of the Institute of Advanced Legal Studies Library for their assistance.

\begin{abstract}
I am sad to report the death of Willi Steiner on 14 May 2003. Willi was Librarian of the Institute of Advanced Legal Studies from 1968 to 1982 and also served as the Secretary of the Institute from 1968 to 1971.

Willi had previously worked at the British Library of Political and Economic Science and at the Squire Law Library of the University of Cambridge. Willi was General Editor of the Index to Foreign Legal Periodicals from 1968 to 1984, having served as Assistant Editor under Howard Drake. He served as a joint general reporter to the International Congress of Comparative Law both in Tehran and in Budapest for the section on documentation and research in law. He had a wide range of international contacts and was a highly respected member of the profession in the UK and overseas. He served on committees of the American Association of Law Libraries and as Vice President of the International Association of Law Libraries. He was a consultant to several major law libraries and constructed classification systems for the Squire Law Library and for the European University Institute in Fiesole where he was appointed Visiting Professor during a period from 1980 to 1982.
\end{abstract}

\begin{abstract}
The British and Irish Association of Law Librarians conferred Life Membership on Willi for his outstanding and distinguished service to the profession. Willi was a founder member of the Association and President of the Association from1985 to 1988 and the first President to be invited from amongst the Association's own members.
\end{abstract}

Many of the staff of the Institute and members of the Association remember him and do so with great respect as well as fondness. ${ }^{1}$

It is important to note that I received a large number of messages from law librarians around the world in response to the notice, including communications from the Squire Law Library, the Bodleian Law Library, Harvard, Yale, Berkeley, the Max Planck Institute in Hamburg, the Swiss Institute of Comparative Law in Lausanne, and the European University Institute in Fiesole among others.

This article bears the same title as the article by the late Wallace Breem, Librarian of Inner Temple and then Vice-President of the British and Irish Association of Law Librarians, almost twenty years ago. ${ }^{2}$ That article appeared in an issue of The Law Librarian in 1984 'devoted to a celebration of the achievements in law librarianship both in Britain and abroad of one of the Association's most distinguished members'. ${ }^{3}$ It was 'dedicated with affection and respect to Willi Steiner' by the new editor of the Association's journal, Barbara Tearle, now President of the Association. The issue marked Willi's 
retirement from the Institute of Advanced Legal Studies; Willi had retired from the post of Librarian in January 1982 and acted as library consultant checking the completeness and consistency of its collections until the following year. The articles within that issue were written by friends and colleagues from the institutions and organisations to which Willi devoted much of his career, people far more qualified than I to chronicle his achievements. The breadth of those articles amply demonstrates Willi's involvement in the profession on an international basis. I hope readers will forgive the inevitable reference to, and borrowing from, these earlier appreciations in order to tell the story of Willi's career.

Willi was one of a generation of continental lawyers from central and eastern Europe who made such a large contribution to research and scholarship in the common law world throughout the second half of the twentieth century. Their expertise facilitated the growth of comparative study of law and the understanding of civil law jurisdictions. Major research libraries in the United Kingdom and the United States (and elsewhere) benefited from the expertise of those lawyers who turned their attention to librarianship and documentalism and they formed the major part of first nucleus of the International Association of Law Libraries which carries on their ideals of collaboration and internationalism. The retirement of this generation has caused no less than a skills crisis in the operation of legal research libraries which seek to maintain collections and services relating to legal systems of continental Europe, so much so that the American Association of Law Libraries has mounted a campaign to train the new generation of foreign and international law librarians.

Wilhelm Anton Friedrich Paul Steiner, later styled William Anthony Frederick Paul Steiner, was born in Vienna on 16 December 1918, his father Richard was a judge and his mother, Paula, a distinguished linguist. Willi in 1968 listed himself as bilingual in German and English, fluent in French, moderately fluent in Italian, and with 'sufficient reading knowledge for the purposes of law librarianship in Dutch, Spanish, Portuguese, Hungarian, Rumanian, Scandinavian and Slavic languages; Latin and Greek'; Willi was a modest man and this was no mere boast.

Both Willi and his brother Franzi, four years his junior, attended the Schottengymnasium in Vienna, which was run by Benedictine monks. "The 'Schotten' was very forward looking and liberal in its views and strongly influenced their religious development. Willi's faith remained the foundation of his life and he was a committed member of his parish church where he served as a reader and Eucharistic minister. In their respective traditions, both Willi and his wife Barbara were also members of the Third Order of St. Francis of Assisi". ${ }^{4}$ Willi completed his schooling in 1936, going on to read law at Vienna University while simultaneously studying at the Consular Academy, an international college of international law and relations. He was awarded an Honours Diploma by the Academy in 1938.

Willi came to England in 1938 as a refugee. He became a member of Gray's Inn and read for the Bar, obtaining a second-class pass in the Bar Finals in 
1941 and being called in the Michaelmas Term 1942. Before call to the Bar, in an act typical of his strong principles, he had volunteered for active service in the British Army but was rejected because of his short-sightedness. He instead served in the war effort as a machine miller in an engineering factory for two years, leaving it only when eye strain caused by the work proved too much of an obstacle; he was released from duty in 1943.

From December 1943 to December 1944, Willi read as a pupil in the chambers of the then Mr. Patrick Devlin, although he never went into practice. At the same time he began reading for the external LLB degree of the University of London, that route which has offered so much opportunity to so many students whose circumstances are not able to accommodate full time study. He was awarded the degree, second class (lower division) in 1945, an extremely swift completion. During this period he became a part-time library assistant at the British Library of Political and Economic Science, later becoming full-time. His first job there was to help unload and re-shelve the books being brought back to London following their wartime evacuation. During the same period from 1945 to 1948 he read for the LLM degree as an internal evening student of the London School of Economics. At that time the University of London LLM degree was by dissertation over two years full-time or more part-time, rather than the present one-year, mainly taught, degree. Willi's dissertation on The transfer of shares and debentures in private international law ${ }^{5}$, which exhibited his continuing interest in matters which crossed borders and legal systems, was submitted in 1948 and he was awarded the degree in that year. A copy of the thesis is in the Library of the Institute of Advanced Legal Studies and was consulted as recently as 1989.

He continued to work at the British Library of Political and Economic Science at the LSE until 1959. By 1953 he had passed the examinations of the Library Association and become a chartered professional librarian, styled an Associate of the Library Association in those days. For several years he was in charge of the legal collections of the Library, which comprised, in addition to the common law collections, the Schuster Library of Comparative Legislation and the Sir Edward Fry Memorial Library of International Law, until he moved to Cambridge in 1959.

His work with the legal collections at the British Library of Political and Economic Science naturally led to close contact with the Library of the Institute of Advanced Legal Studies of the University of London and with his opposite number there, Barbara Smith. Barbara had taken a degree in Classics at Bedford College, University of London, and had been appointed as the first permanent Assistant Librarian at the Institute. They were married on July $1^{\text {st }} 1950$ in what K. Howard Drake, then Secretary and Librarian of the Institute, used to refer as an outstanding example of co-operation between London law libraries. These early years until her retirement from the Institute in September 1951 and the subsequent award to her in 1975 of the Fellowship of the Library Association are described by Barbara Steiner in an article in $1995 .^{6}$ (Willi would wait until 1981 for the award of his Fellowship.) This was the start of over half a century of happy marriage, with Barbara as the strong support of Willi's professional career. Barbara retained a 
professional interest and involvement, working on various projects, and always retained Willi's respect as a professional colleague.

Willi took up the post of Assistant Librarian of the Squire Law Library of the University of Cambridge in 1959. Three years later the degree of MA was conferred on him by virtue of his office and in the same year he became an honorary member of Sidney Sussex College where he enjoyed dining regularly. At the time he was the senior full-time member of staff of the Library and the only professional librarian, and primarily responsible for running the library. An academic teacher was the Librarian on a part-time basis; Ellis Lewis was a legal historian who made a career as a lecturer, editor of Winfield, and a much respected and loved supervisor. Willi notes that "It will be obvious that the co-operation between us might have been awkward. This was not the case; it was, on the contrary, cordial and harmonious throughout...."7 The only other staff were two longstanding assistants without formal training in either law or librarianship, one of whom was at least in part working as Faculty Secretary. In many ways the Squire Law Library had reached a point where major changes were required: the form of fixed location system for common law literature was under strain as the holdings increased; the lack of subject access to much of the collections was an increasing difficulty; and the number of undergraduates had trebled in very recent years. Willi, as Assistant Librarian within this somewhat ambiguous situation managed to transform the Library and, at the same time, impressed the whole Faculty with his pleasant manner, his approachability and helpfulness whether with an individual recherché request or a simple question from an undergraduate.

By 1968, Clive Parry, then Chairman of the Library Committee, could write that Willi had succeeded in transforming the Library. The Squire in 1968 held about 60,000 volumes, including substantial holdings of English, Commonwealth, American, foreign and comparative law; Willi was credited with adding about a quarter of its collections. Willi had instituted regular instruction in legal bibliography and the use of the library to both undergraduates and research students. He had also tackled two major projects, the computerisation of the catalogue and the great reclassification of the library.

When Willi joined the Squire Law Library it was clear to him "that it was essential not only to re-classify all the library's contents and assign classmarks instead of shelf-marks, but also to re-catalogue since the Squire had outgrown its catalogues which had been designed for a different and smaller library". "The Squire had also outgrown its premises. The reclassification was made possible, and indeed necessary, by the rearrangement following the addition of space to the library.

Recataloguing a whole library, even at the then size of the Squire, was a massive undertaking but one to which Willi was particularly well suited. His clear good sense and painstaking attention both to detail and to the overall integrity of the project were well tested and not found wanting. The computerised cataloguing was an early application of computers in the field, 
utilising a programme developed at Cambridge to produce a union catalogue of scientific literature and running on a 'Titan' computer at the Mathematical Laboratory. A flavour of this early experiment can be gathered from the procedure of recording catalogue data on forms to be transferred to punched paper tapes and thence to magnetic tape; the final printed version is instantly recognisable as early computer output. Willi himself wrote an early article about the use of computers in the production of library catalogues ${ }^{9}$ and the introductions by Willi to the printed catalogues described below contain further details. No-one could be said at that time to have the technical knowledge of computerisation of libraries and, although Willi had no great love for such matters, the knowledge he gained during the project would stand him in good stead, particularly during the computerisation of the typesetting and printing of the Index to Foreign Legal Periodicals some years later.

A catalogue of international law was published in 1972 in four volumes. ${ }^{10}$ The project achieved its fulfilment with the publication of the complete printed catalogue of the Squire Law Library, incorporating the international law collections, in 14 volumes by Oceana in $1974 .{ }^{11}$ The computerisation had made possible the generation of the data, entered once into the system, in various orders, a breakthrough worth noting prominently at the time. The printed catalogue offered an author catalogue, which actually extended to a name catalogue with the subjects of biographies, etc., a subject catalogue offering both subject main entry and jurisdiction main entry, a periodicals list which included collections of legislation by jurisdiction and a variety of other lists of national and international official documents. For many years, until the availability of a modern generation of web-enabled library systems, this was an important work of reference and no doubt it gave a stable foundation for the development of the library itself. It was regretted that there was no supplement to that outstanding work (made impossible by the retirement of Titan in the early 1970s and with it, in the nature of early computing, the programme that had created the catalogue and the machine-readable data). It should be mentioned that one of the team of cataloguers which undertook the work was, of course, a certain Mrs B. K. Steiner.

As Clive Parry notes in his foreword to the catalogues, "perhaps this reclassification is more important than the re-cataloguing." The classification which Willi devised was flexible, compact in notation but detailed and offered the Faculty a choice of main arrangement, a choice which they made in favour of jurisdiction. The classification itself was published as an appendix volume ${ }^{12}$ to the printed set. The system itself never gained adoption by other libraries in the way the Betty Moys system did, despite its intellectual rigour, because it was designed for the Squire and not as a general system. The Squire however continues to be organised according to Willi's unique, comprehensive scheme and, whereas other libraries the world over have changed to other classification systems, there are no such plans at Cambridge.

The printed catalogue displays the classification scheme's qualities in application admirably. It perhaps performs better in that form in which it was intended than in its appearance on the shelves where the mnemonic qualities 
of its notation were a stern test. In many ways the printed catalogue remains the most authoritative and convenient method of searching the early acquisitions (1904-1971) of the Squire, despite the advancements of electronic catalogues.

The post at the Squire Law Library involved certain administrative duties including acting as Secretary to the Library Committee and, in practice, preparing the draft quinquennial and annual statements of needs for the Library Committee and the Faculty Board. Willi supervised the keeping of the Library's accounts, and, owing to the close connection between the Library and the Faculty administrations, to some extent also the keeping of the Faculty's accounts. He notes, in typically understated terms, that during 1967 and 1968, 'I have experienced the problems caused by the mechanisation of the University's accounting system'. In this, as in other things, Willi was ahead of his time.

Willi made himself available for a wide range of related activities including the Index to Foreign Legal Periodicals and the Society of Public Teachers of Law (both described later in this article), a variety of committees and in other bibliographic work during his time in Cambridge. He was a member from 1962 of the Editorial Board of the Cambridge Law Journal and was, from 1963, the Assistant Book Review Editor. In the latter capacity he was responsible for preparing and seeing though the press the annual index and tables and the covers of all issues, in addition to assisting the Book Review Editor. During the period he wrote a number of book reviews and notices for the Journal of Documentation, Modern Law Review, and Cambridge Law Journal.

Willi by 1968 was also Chairman of the Committee on Libraries of the World Peace Through Law Center, a member of that Center's Standing Committee of Experts on the Computerisation of Law in Europe, and one of the representatives of the International Association of Law Libraries on the Center's planning committee. The name of the Center not only demonstrates his continuing interest in international matters but also his profoundly moral approach to his profession. This work was twinned with a considerable involvement in the International Association of Law Libraries and the first stirrings of interest in the establishment of a national association in the UK.

In September 1964 the Bodleian Law Library opened in its new premises at the St. Cross Building designed by Sir Leslie Martin; the official opening on 17 October was attended by a number of law librarians. It was followed by a Symposium on law libraries at the meeting of the Society of Public Teachers of Law in Birmingham. This event in retrospect has the look of a turning point: a new and very modern major legal research library building at Oxford, the brink of computerisation, not long before of the loss of one generation of law librarians, pre-eminently K. Howard Drake, and the emergence of a new, such as Willi. Perhaps this is fanciful at this distance. The symposium is recorded in the Journal of the Society of Public Teachers of Law ${ }^{13}$ in which papers by Howard Drake of the Institute of Advanced Legal Studies, Peter Carter of Wadham College, and Willi Steiner of the Squire Law Library appear. This may have been the last time that representatives of these three major legal 
research libraries appeared on the same platform until the Joint Study Institute of the American, British and Irish, and Canadian Associations of Law Libraries in 1998 hosted at the new Faculty of Law building in Cambridge (although I believe Willi once told me that in fact he was not present at the Symposium but his paper was kindly read in his absence). ${ }^{14}$

Just before leaving the Squire in 1968 Willi made one last contribution to the future success of the library, although at the time he would not have realised its significance. As he was about to move on from Cambridge Willi was involved in the appointment of Peter Zawada as a junior library assistant. Unbeknown to him then, that appointment was to be crucial for the future continuity of the library through some difficult times ahead. Nearly thirty-five years on Peter, now Assistant Under-Librarian and Deputy to the Librarian, has played a crucial reader services role in the development of the Squire. Willi's judgement in recruitment matters was clearly good; he appointed to their first law library posts many young people who have stayed in the profession including Guy Holborn, now Librarian of Lincoln's Inn, and indeed your author!

In 1968 Willi was appointed as Secretary and Librarian of the Institute of Advanced Legal Studies of the University of London, following the sudden death at the age of 52 of Howard Drake, the acknowledged British representative of law librarianship and a legendary figure. Appointed in April, he took up his post on $1^{\text {st }}$ August 1968. The appointment was crucial to the development of the Institute which had been debating whether a librarian could be found who might tackle the administration required or whether an administrator could be found who might pick up the necessary amount of the profession of law librarianship and whether either could be found who was a lawyer. Thankfully the right decision was made with a careful steer from Muriel Anderson.

An issue arose on appointment in relation to the normal requirement that the person appointed should reside not more than thirty miles from the Senate House of the University of London. Willi was specific in his application that the power to waive this requirement should be exercised by the Management Committee of the Institute if he were to be appointed and it duly was waived. The occupation of the family home at 10 Cavendish Avenue was set to continue for many years. Some speculated that Willi would need to stay over in London on several nights each week but the journey to Cambridge from the nearby King's Cross station proved to be a valuable opportunity to check the batches of indexing slips for the Index which accompanied him everywhere.

Willi's short-sightedness was obvious because of his very thick glasses, although it never appeared to be a handicap to his work or social life. When staff happened to leave the Institute at the same time, they took their life in their hands. He would cross the road immediately outside the Institute at a corner where, despite the pedestrian crossing, cars approached at an alarming rate. It seemed that these approaching cars were only a vague blur to Willi who remained on the pavement until he could detect no movement and then scurried swiftly across, leaving any companion to follow instinctively 
a dangerous split second later. It seemed nothing short of a miracle when surgery in later life allowed him to discard spectacles, revealing such an open and kindly face, and also giving one severe misgivings when one saw him without glasses at the kerbside waiting to cross the road.

Professor Aubrey Diamond, Director of the Institute at the time of Willi's retirement opened his description of Willi's tenure ${ }^{15}$ :

"Willi presided over the Library of Institute of Advanced Legal Studies for more than a third of its existence, and saw it grow from a collection of 90,000 volumes in two old houses in Russell Square (with several overflows in other locations) to more than 150,000 volumes in a fine modern, purpose-built library on five floors of a single building."

The Institute and its library, although essential features of the outstanding postgraduate and research programmes in law of the University of London, were already very much national and international research facilities and this is reflected in the projects in which Willi was involved.

Although the posts of Secretary and Librarian of the Institute were still combined at the time Willi was appointed in 1968, a full-time Secretary was appointed in 1971 and Willi became full-time Librarian. This was probably somewhat of a relief to Willi who was temperamentally not inclined to such administrative tasks, no matter how conscientiously he performed them. It was also a matter of necessity as Willi describes:

"While this system [a combined post of Secretary and Librarian] had some advantages, particularly in the early days of an Institute, it was basically flawed in that the holder of the combined post could be neither full-time Secretary nor full-time Librarian, and that a heavy burden was placed on his full-time deputies of whom there were two at the Institute. The arrangement became unworkable at the Institute when, from the late nineteen-sixties, the time of the three officers involved as well as that of the Director became increasingly taken up with the work on the new building of the Institute" 16

Plans for permanent purpose-built premises were under discussion by the mid nineteen-sixties and the new building opened in January 1976. The process of planning, building, relocating and adapting to the new building took not less than a decade and probably somewhat longer. That the Institute worked so well and developed so well, despite the enormous burden of this move, is a credit to the teamwork of the two most senior library staff, Willi and his Deputy and later successor Muriel Anderson, who complemented each other so well and so successfully.

While at Cambridge Willi had been Assistant Editor to Howard Drake, General Editor of the Index to Foreign Legal Periodicals from its inception in 1959. The two law librarians in England carried through the project which had been planned and brought into existence in the USA. At the time of Willi's appointment at the Institute, William B. Stern at the Los Angeles County Law Library, Chairman of the Committee on Foreign Law Indexing of the American Association of Law Libraries and moving force behind the establishment of the Index, negotiated with Professor, later Sir, Norman Anderson, that Willi should 
take over the General Editorship of the Index. This ensured the continuity of the publication and put in place a major part of Willi's career over many years, both in professional terms and in terms of his circle of friends and colleagues in the USA.

Willi's Editorship would last for seventeen years until after his retirement from the Institute and he handed over to Tom Reynolds at the University of California at Berkeley in 1984. The development of the Index has been described in detail by Tom Reynolds at the time ${ }^{17}$ and in a tribute to Willi recently published in the Index. Willi himself recognised that the editing and publication of the Index brought many benefits to the Institute, enabled a close relationship to be maintained with American Association of Law Libraries, and also, as he wrote, "Mr. Steiner owes many friendships, some of them very close, to his Editorship of the Index". ${ }^{18}$

The American Association of Law Libraries had presented Willi with a prized certificate of competence in 1968. In 1982, in recognition of his work as General Editor of the Index, the American Association of Law Libraries presented Willi with a plaque on his retirement with the inscription: "By use of wit, intelligence and devotion, you made the Index into the major resource of its kind in the world. Your labour, creativity and accomplishments are deeply appreciated."

Willi undertook a major tour of law libraries, law schools and other legal institutions in the United States in 1972 lasting seven weeks and culminating in attendance at the annual meeting of the American Association of Law Libraries in Chicago. His file note on the itinerary gives a list of some of the most eminent law librarians of the time. He also notes in passing:

"On Monday, $3^{\text {rd }}$ July, a meeting of the Standing Committee on ... took place at 8 p.m. I had convened this meeting as Chairman of the Committee. Only one other member of the Committee attended in addition to two non-members who looked in because they had been under a misapprehension as to its function and thought they would be interested in its work. I cannot claim that the meeting was in any way profitable."

One can almost see that familiar mischievous twinkle in Willi's eye.

In 1964, while at the Squire Law Library, Willi had been a member of the Committee of the Society of Public Teachers of Law which prepared the memorandum submitted to the University Grants Committee's Committee on Libraries. The Society had had close connections with the Institute since Howard Drake had been its Assistant Honorary Secretary from 1950 to 1960. Willi became Convenor of its Sub-Committee on Libraries from its formation, having served on the Minimum Standards Sub-Committee which produced the first publication of the Society's guidance to universities on law libraries in $1970^{19}$, and he served in that capacity until 1989, long after his formal retirement from the Institute.

Willi was a member of the Council of the United Kingdom National Committee of Comparative Law. He attended the $6^{\text {th }}$ International Congress of 
Comparative Law in Hamburg with Howard Drake when the Bibliographical Section was instituted, as Willi notes "in some ways a by-product of the Index to Foreign Legal Periodicals" ${ }^{20}$ He continued to attend the Congresses held every four years over the next twenty years until his retirement: in Uppsala in 1966, in Pescara in 1970 where he was President of the Bibliographic Section, in Teheran in 1974 where he was General Reporter of the Section, in Budapest in 1978 and in Caracas in 1982.

In 1975 Willi began to advise the Committee of Vice Chancellors and Principals of the Universities of the United Kingdom of any proposed legislation and important judicial decisions which might affect universities and their work. There is no record of when this task came to an end.

Willi was Second Vice-President of the International Association of Law Libraries from 1974 to 1976 and First Vice-President from 1976 to1980 and a staunch supporter and life member. The Association had been founded in 1959 with Howard Drake as one of the founder members and its President at the time of his death. The Association's early history, with reference to Willi, is chronicled by the late Adolf Sprudz. ${ }^{21}$ As he describes, the International Association grew out of the efforts of a Special Committee on an International Association of Law Libraries, established by the American Association of Law Libraries in June 1958, among whose members was Howard Drake. Willi was involved early in the International Association's life and attended the first meeting of European members which took place at The Hague in April 1965, as one of the two UK representatives. He spoke on the use of computers in law libraries at its first annual course in law librarianship in Luxembourg in the autumn of 1966 and the paper appeared in the Bulletin of the Association in the following year. ${ }^{22}$ At that course, he also mentions chairing a "somewhat turbulent meeting" of the Association ${ }^{23}$ but we learn no other details.

Willi was the joint director with Muriel Anderson of the second course in international law librarianship which was held by IALL in Cambridge in March 1968. He distinguished himself, according to an impeccable source, not only for the quality of the programme but by familiarity with "all the best watering holes and an uncanny knowledge of the City after dark." ${ }^{24}$ At this time work was proceeding on the European law libraries guide ${ }^{25}$ co-ordinated at the Institute of Advanced Legal Studies after the International Association had been invited by the Council to prepare it. Willi was a member of the Editorial Committee of that publication and an Associate Editor of the International Journal of Law Libraries in 1980.

The British and Irish Association of Law Librarians was established in 1969, the year after Willi joined the Institute of Advanced Legal Studies. In his application he mentioned that he was a member of the steering committee set up recently to investigate the possibility of forming an association of British law libraries or librarians. The formation of the British and Irish Association of Law Librarians is detailed in Mary Blake's History ${ }^{26}$ of the Association. Willi attended the famous workshop on law librarianship at Harrogate in February 1968. As Mary describes: 
"Following the final talk of the Workshop by Willi Steiner and Betty Moys on the International Association of Law Libraries (IALL) it was resolved to set up a British section, and an ad hoc Committee was appointed to look into the possibility and invite people's views. The members of this committee were Wallace Breem (who volunteered to send a circular to all law libraries), Don Daintree, Betty Moys, Willi Steiner and Derek Way. Replies to the circular were so encouraging that at the second Workshop in April 1969 the Association of Law Librarians was formally established." 27

Willi became a founder member of the Association and a member of the Executive Committee from 1969 to 1975. He chaired the Sub-Committee, later Standing Committee, on Cataloguing and Classification from 1974 to 1980, chaired the Sub-Committee on Crown Court Libraries from 1972 to 1976 and chaired the Sub-Committee on Law Library Provision from 1976 to 1977. Eventually he became the first President to be invited from among the membership and served from 1985 to 1988 in that capacity. Life membership was conferred on him for outstanding and distinguished service. As Wallace Breem recalled in $1984^{28}$, "'let's ask Willi' was close to becoming a catch phrase amongst those administering the Association's affairs" during the early years of the Association.

Willi was responsible for the tenth annual conference of the Association in Cambridge in 1979. The conference was hosted at Sidney Sussex College and attended by 98 members out of the membership of 220. It was an extremely successful conference with a memorable annual dinner in hall. On discovering that, although electric cooking rings were available in the staircase kitchens, there were no kettles for the vital late night coffee parties, Willi set out and bought a large number of hob kettles and distributed them along with the other necessary supplies. Some delegates had of course come up with other solutions involving bottles and glasses. The kettles were taken back to the IALS in case they might be used on another occasion and languished there for some considerable time.

The Manual of Law Librarianship edited by Betty Moys ${ }^{29}$ for the British and Irish Association of Law Librarians became the leading work for the profession when it was published in 1976. Willi was the author, appropriately, of the chapter on foreign law. By the publication of the second edition in $1987^{30}$, he was President of the Association and contributing the foreword in that capacity.

In addition to consolidating the library of the Institute of Advanced Legal Studies, moving it to its new accommodation, and playing a role in many of the University of London's library committees and working parties, Willi maintained the Institute's central position in legal education nationally and internationally. Willi, through his work with the Index formed contacts across the world and kept the vital contact with the American Association of Law Libraries through regular attendance at the AALL's annual meeting. He managed to find time to attend meetings and courses and visit libraries and legal institutions in many countries. In 1975 he lectured at a workshop for Law 
Librarians in Lagos which was held under the auspices of the Federal Supreme Court of Nigeria.

Willi gave his advice freely and without any thought of personal prestige. He was perhaps a man most free of the need to make personal capital of his position. Although he was free with his praise for the achievements of others, he was exceptionally modest of his own achievements.

However this may be, his advice was sought by individuals and institutions. Two pre-eminent institutions in their field made use of Willi's services: the European University Institute in Fiesole near Florence and the Swiss Institute of Comparative Law in Lausanne, where he was a member of the Library Commission. Willi was invited to undertake a complex and extended consultancy at the European University Institute in order to draw up a new classification for law in the context of the work of the EUI, a task for which he was uniquely qualified. For a part of each year, for several years, he and Barbara and Barbara's sister Constance stayed in Fiesole while Willi worked on the classification and the law collections of the Institute. In 1984 Kenneth Humphreys, former Librarian of the European University Institute and, at the time, President of the British and Irish Association of Law Librarians, wrote about the European University Institute and Willi, noting "The final text is a triumph of a logical philosophy combined with an inspired practicality". ${ }^{31}$ Willi was appointed Visiting Professor during the period 1980 to 1982 and continued his visits to supplement the scheme until 1986.

Not surprisingly Willi's retirement proved to be nothing of the sort and he remained busy almost throughout his retirement. As previously noted, he continued to work for various organisations including the Society of Public Teachers of Law (now the Society of Legal Scholars). He wrote about the Institute of Advanced Legal Studies including a note in the volume celebrating fifty years of the Institute ${ }^{32}$, an article in the IALS Bulletin on the establishment of the Institute ${ }^{33}$, and a detailed account of the first thirty years of the Institute's history until its move to its existing home at 17 Russell Square completed and published by the Institute in $2000 .^{34}$

A new project came his way in the 1990s which he described in the Festschrift for one of his international colleagues, Jan Stepan. ${ }^{35}$ His brother mentions this in the Times obituary with some affectionate personal details.

"In the early 1990s he spent several months in Vienna as part of a team editing the pre-1914 Austrian Digests of Diplomatic Practice. For this work the Academy of Sciences in Vienna had to recruit a team of scholars educated before the last war since the younger generation of diplomatic historians could not cope with the traditional Gothic script in which the nineteenth century records were written. It seemed fitting that during this late stage of his career he and his wife should stay in the guest house of the 'Schotten' Abbey, the monastery at which he had been to school and where his parents had been married over 70 years before." 36 
Willi remained an honorary member of the Faculty of Law of the University of Cambridge after he moved to the Institute and throughout his life. The Squire always remained close to his heart and after his retirement from the Institute, Willi wrote a history of the Squire Law Library ${ }^{37}$, undertook part-time cataloguing and bibliographic work for the library, interested himself in the life of the Faculty and in particular the plans for the new Faculty building incorporating the Squire Law Library on the Sidgwick site. Willi and Barbara attended events organised by the Institute of Advanced Legal Studies and the Society of Advanced Legal Studies in London from time to time and the subject of the new building in Cambridge was carefully avoided by Barbara at times because of the excitement and perturbation it caused him. The stunning new building by Sir Norman Foster was completed in 1995 incorporating some of the features advocated by Willi. He had been involved at the Squire in the expansion of its premises at the start of his time in Cambridge, at the symposium following the opening of the new Bodleian Law Library mentioned above, in the move to the new building of the IALS, and, full circle, in the move to the new building of the Squire towards the end of his career. Even after the move into the building Willi continued to visit the Squire on a regular basis providing encouragement and offering advice in connection with the foreign and international law collections.

Willi wrote, "I became a law librarian by accident and not by design. ... Law librarianship as a profession did not then exist outside the United States". ${ }^{8}$ By the time Willi retired the profession of law librarianship certainly did exist and by no small measure through his influence and success. A lucky accident, as good lives tend to have, with full advantage taken of it.

Willi's family wrote:

"Barbara and Willi celebrated their Golden Wedding anniversary in 2000 with their four children, Richard, Margaret, Mary and Anne and their five grandchildren. Their marriage brought them both very great happiness and when Willi experienced poor health in the last couple of years, Barbara cared for him unstintingly, both at home and in his last year at the Hope Nursing Home in Cambridge.

Willi was a delightful man, very kind and gentle, and someone who always showed great courtesy and thoughtfulness for others. He was also a person of high standards and fierce integrity, who showed unswerving loyalty to those he cared for. Willi also had a very mischievous twinkle in his eye and a store of terrible jokes. He was certainly eccentric, and found huge delight in discovering others as eccentric as himself.

All who were lucky enough to have known Willi and to have been cared for by him, will feel the loss of someone very special. Someone with a fascinating family history that was such an important part of who he was; someone with a deep love of books and learning; someone with an unswerving Faith and belief in goodness and someone who gave all of himself for those he loved." 


\section{Bibliography}

\section{Books and chapters}

The Austro-Hungarian Digest of State Practice in the field of Public International Law in context in Festschrift für Jan Stepan zum 80. Geburtstag. Publications de l'Institut suisse de droit comparé, 23. Zurich: Schulthess, 1994, p. 37-46

Classification scheme and list of subject headings for the Squire Law Library, University of Cambridge. Dobbs Ferry, NY: Oceana, 1974.

Documentation and research in law. In International Congress of Comparative Law. 10 ${ }^{\text {th }}$, Budapest, 1978. General reports, 999-1022. Budapest: Akadémiai Kiadó, 1981

Foreign law in Manual of Law Librarianship edited by Elizabeth Moys. London: Andre Deutsch for the British and Irish Association of Law Librarians, 1976, p. 297-336

The Institute of Advanced Legal Studies 1947-1976. London: IALS, 2000.

Libraries and scientific and cultural institutions by W. A. Steiner. In Halsbury's Laws of England $4^{\text {th }}$ edition, volume 28 [original issue]. London:

Butterworths, 1979, 145-218

A note on the Institute of Advanced Legal Studies in Law at the Centre: the Institute of Advanced Legal Studies at fifty edited by Barry A. K. Rider. London: Kluwer Law, 1999, 1-18

Possibility and limits of the unification of methods of using computers in the field of law. In International Congress of Comparative law. $9^{\text {th }}$, Teheran, 1974. Rapports généraux, 849-863

The Squire Law Library of the University of Cambridge. W. A. F. P. Steiner. In Bibliothek und Recht - International: Festschrift Ralph Lansky edited by J. Gödan and $\mathrm{H}$. Knudsen. (Arbeitshefte der Arbeitsgemeinshaft für Juristisches Bibliotheks- und Dokumentationswesen, no.15) Hamburg, Augsburg: AJBD, 1991, 243-294

Transfer of shares and debentures in private international law. LLM Thesis, London, 1947. 73 pages.

University of Cambridge. Squire Law Library. Catalogue of international law compiled by M. A. Lekner under the direction of W. A. F. P. Steiner. 4 vols. Dobbs Ferry, NY: Oceana, 1972

University of Cambridge. The Squire Law Library. Law catalogue. Compiled by M. A. Lekner under the direction of W. A. F. P. Steiner. 14 vols. Dobbs Ferry, NY: Oceana, 1974

\section{Articles in periodicals}

Aiding and abetting - Aliens Order 1920 [Wilcox v. Jeffery [1951] 1 All ER 464] (case note). Modern Law Review vol.14, 1951, 361-363

Dewey Decimal Classification: Law. Law Librarian vol.4, 1973, 14-15

Charles Henry Alexandrowicz. British Year Book of International Law vol.47, 1974/75, 269-271

Computerisation of law in Europe European Yearbook vol.15, 1967, 102-116 The establishment of the Institute of Advanced Legal Studies of the University of London, IALS Bulletin no.17, April 1994, 6-20. 
Extraterritorial effect of statutes - raising new points in the Court of Appeal tort committed abroad [Yorke v. British and Continental Steamship Co. Ltd. 78 LI.L.R. 181] Modern Law Review vol.9, 1946, 184-9

Future trends in international law librarianship. Law Librarian vol.26, 1995, 316-320

In memory of Kenneth Howard Drake. Law Library Journal vol.61, 1968, 155156

Law and taxation in the EEC and its member countries. ASLIB Proceedings vol.24, 1972, 514-524

Muriel Anderson - an appreciation. IALS Bulletin no.8, April 1991, 4-5

Muriel Anderson - a profile. Law Librarian vol.22, 1991, 110-112

Papers in early American prize cases. Journal of Documentation vol.4, 1948, 90-91

Problems and possibilities of indexing legal periodical literature in the international field. International Journal of Law Libraries vol.1, 1973, 49-61

Recent periodical literature. Modern Law Review vol.9, 1946, 313-15

Some problems of classification in international and comparative law. International Journal of Legal Information vol.10, 1982, 320-325

The Squire Law Library at Cambridge. Journal of the Society of Public Teachers of Law NS vol.8, 1964/65, 85-88 (Symposium on law libraries)

Thesaurus problems as exemplified by the Index to Foreign Legal Periodicals. (Paper presented to the International Federation of Library Associations $39^{\text {th }}$ General Council, Grenoble 1973) International Journal of Law Libraries vol.2, 1974, 5-13

The use of computers in law libraries. Bulletin of the International Association of Law Libraries no.19, April 1967, 37-53

\section{Book reviews}

A classification scheme for law books by Elizabeth M. Moys. Cambridge Law Journal 1968, 335-336

Bibliography of Hungarian legal literature, 1945-1965 edited by Lajos Nagy. Cambridge Law Journal 1967, 288

Copyright law symposium number ten: Nathan Burkan Memorial Competition sponsored by the American Society of Composers, Authors, and Publishers. Journal of Documentation vol.16, 1960, 148-150

Germain's transnational law research: a guide for attorneys by Claire Germain. Law Librarian vol.23, 1992, 164

Im Dienste des Rechts und der Rechtsliteratur. Festschrift für Helmut Dau... edited by R. Lansky and R.-E. Walter. Law Librarian vol.24, 1993, 49-51

International legal bibliographies: a worldwide guide and critique by J. Gödan. Law Librarian vol.23, 1992, 213-214

Die internationalen allgemeinjuristischen Fachbibliographien by J. Gödan. Law Librarian vol.8, 1977, 14

Internationales Urheberrecht by W. Bappert and E. Wagner. Journal of Documentation vol.14, 1958, 81-82

Law relating to hospitals and kindred institutions by S. R. Speller. Modern Law Review vol.11, 1948, 373-4

Manual of legal citations. Part I: the British Isles edited by G. D. Nokes. Cambridge Law Journal 1960, 350-351 
Manual of legal citations. Part II: the British Commonwealth edited by G. D. Nokes. Cambridge Law Journal 1961, 132

Manual of procedures for private law libraries edited by L. F. Jessup et al. Journal of Documentation vol.19, 1963, 27

Manual of procedures for private law libraries. $2^{\text {nd }}$ edition by E. Foley. Journal of Documentation vol.22, 1966, 266

Où trouver le texte des traités européens by Michel Roussier. Journal of Documentation vol.14, 1958, 215

Study of hospital administration by F. Hart and A. J. Waldegrave. Modern Law Review vol.12, 1949, 533-534

\footnotetext{
${ }^{1}$ W.A.F.P.Steiner LLM (London), MA (Cantab), FLA, of Gray's Inn, Barrister-at-Law. Notice by Jules Winterton which appeared on electronic discussion list, on the British and Irish Association of Law Librarians website and was reproduced in Legal Information Management vol.3, no.2, Summer 2003, 47

${ }^{2}$ In celebration of Willi Steiner: a personal introduction. Wallace Breem. Law Librarian 15, 1984, 36-38

${ }^{3}$ Law Librarian volume 15, no.3, December 1984.

${ }^{4}$ Willi Steiner 16 December 1918 - 14 May 2003. Handbill compiled by the family for Willi's funeral

${ }^{5}$ Transfer of shares and debentures in private international law. LLM Thesis, London, 1947. 73 pages

${ }_{7}^{6}$ Early days at the IALS. Barbara Steiner. IALS Bulletin no.21, October 1995, 9-11

${ }^{7}$ The Squire Law Library of the University of Cambridge. W. A. F. P. Steiner. In Bibliothek und Recht - International: Festschrift Ralph Lansky edited by J. Gödan and H. Knudsen.

(Arbeitshefte der Arbeitsgemeinshaft für Juristisches Bibliotheks- und Dokumentationswesen, no.15) Hamburg, Augsburg: AJBD, 1991, 243-294 at 269

${ }^{8}$ Reclassifying the Squire Law Library. Keith McVeigh. Law Librarian vol.15, 1984, 48-49

${ }^{9}$ The use of computers in law libraries. Willi Steiner. Bulletin of the International Association of Law Libraries no.19, April 1967, 37-53

${ }^{10}$ University of Cambridge. The Squire Law Library. Catalogue of international law. Compiled by M.A.Lekner under the direction of W. A. F. P. Steiner. 4 vols. Dobbs Ferry, NY: Oceana, 1972

${ }^{11}$ University of Cambridge. The Squire Law Library. Law catalogue. Compiled by M. A.

Lekner under the direction of W. A. F. P. Steiner. 14 vols. Dobbs Ferry, NY: Oceana, 1974

${ }^{12}$ Classification scheme and list of subject headings for the Squire Law Library, University of Cambridge compiled by W. A. F. P. Steiner. Dobbs Ferry, NY: Oceana, 1974

${ }^{13}$ Symposium on law libraries. Law Libraries by K. Howard Drake; The new Bodleian Law Library by P. B. Carter; The Squire Law Library at Cambridge. W. A. Steiner. Journal of the Society of Public Teachers of Law NS vol.8, 1964/65, 71-88

${ }^{14}$ Law Librarian vol.30, no.1, March 1999 contained papers from the Joint Study Institute 1998

${ }^{15}$ Willi Steiner and the Institute of Advanced Legal Studies. Aubrey L. Diamond. Law Librarian vol. $15,1984,46-48$

${ }^{16}$ The Institute of Advanced Legal Studies of the University of London 1947-1976. W. A.

Steiner. London: IALS, 2000. At page 12

${ }^{17}$ Indexing of legal journal literature and the history and development of the Index to Foreign Legal Periodicals. Thomas H. Reynolds. Law Librarian vol.15, 1984, 38-46

${ }_{18}$ The Institute of Advanced Legal Studies of the University of London 1947-1976. W. A.

Steiner. London: IALS, 2000. At page 34

${ }^{19}$ Statement of minimum holdings for law libraries in England and Wales with an introduction by J.C. (Sir John) Smith. Journal of the Society of Public Teachers of Law vol.11, 1970, 93103

${ }^{20}$ The Institute of Advanced Legal Studies of the University of London 1947-1976.

W.A.Steiner. London: IALS, 2000, p.43

${ }^{21}$ The International Association of Law Libraries and its twenty-five years of activities. Adolf Sprudz. Law Librarian vol.15, 1984, 50-53
} 
${ }^{22}$ The use of computers in law libraries. Willi Steiner. Bulletin of the International Association of Law Libraries no.19, April 1967, 37-53

${ }^{23}$ A note on the Institute of Advanced Legal Studies. W. A. Steiner. In Law at the centre: the Institute of Advanced Legal Studies at fifty edited by Barry A. K. Rider. London: Kluwer Law, $1999,1-18$ at 7

${ }^{24}$ In celebration of Willi Steiner: a personal introduction. Wallace Breem. Law Librarian vol.15, $1984,36-38$ at 37

${ }^{25}$ European law libraries guide. Prepared by the International Association of Law Libraries under the auspices of the Council of Europe. London: Morgan-Grampian, 1971

${ }^{26}$ A history of the British and Irish Association of Law Librarians 1969-1999. Mary Blake. Warwick: BIALL, 2000

${ }^{27}$ A history of the British and Irish Association of Law Librarians 1969-1999. Mary Blake. Warwick: BIALL, 2000, 4

${ }^{28}$ In celebration of Willi Steiner: a personal introduction. Wallace Breem. Law Librarian vol.15, $1984,36-38$ at 37

${ }^{29}$ Manual of Law Librarianship edited by Elizabeth M. Moys. London: Andre Deutsch for BIALL, 1976

${ }^{30}$ Manual of Law Librarianship $2^{\text {nd }}$ edn. by Elizabeth M. Moys. Aldershot: Gower for BIALL, 1987

${ }^{31}$ The European University Institute and Willi Steiner. Dr. K. Humphreys. Law Librarian vol. $15,1984,54-55$ at 55

${ }^{32}$ A note on the Institute of Advanced Legal Studies. W. A. Steiner. In Law at the centre: the Institute of Advanced Legal Studies at fifty edited by Barry A. K. Rider. London: Kluwer Law, 1999, 1-18

${ }^{33}$ The establishment of the Institute of Advanced Legal Studies of the University of London. Willi Steiner. IALS Bulletin no.17, April 1994, 6-20

${ }^{34}$ The Institute of Advanced Legal Studies of the University of London 1947-1976. W. A. Steiner. London: IALS, 2000

${ }_{35}$ The Austro-Hungarian Digest of State Practice in the field of Public International Law in context. W. A. Steiner. In Festschrift für Jan Stepan zum 80. Geburtstag. Publications de I'Institut suisse de droit comparé, 23. Zurich, Schulthess, 1994, p. 37-46

${ }^{36}$ W.A.Steiner. Obituary by F.Steiner. Times 27 May 2003

${ }^{37}$ The Squire Law Library of the University of Cambridge. W. A. F. P. Steiner. In Bibliothek und Recht - International: Festschrift Ralph Lansky edited by J. Gödan and H. Knudsen. (Arbeitshefte der Arbeitsgemeinshaft für Juristisches Bibliotheks- und Dokumentationswesen, no.15) Hamburg, Augsburg: AJBD, 1991, 243-294

${ }^{38}$ Memories of pre-history from Willi Steiner. In A history of the British and Irish Association of Law Librarians 1969-1999 by Mary Blake. Warwick: BIALL, 2000, 89-91 